Vol. 44, N. 1 : pp. 1 - 6, March, 2001 ISSN 1516-8913 Printed in Brazil

\title{
Activity Determination of $\mathrm{Na}^{+} \mathrm{K}^{+}$- ATPase and $\mathrm{Mg}^{++}$- ATPase Enzymes in the Gill of Poecilia vivipara (Osteichthyes, Cyprinodontiformes) in Different Salinities
}

\author{
Marcelo da Cunha Amaral ${ }^{1}$, Ana Cristina Teixeira Bonecker ${ }^{1 *}$ and Cláudio H. D. Ortiz ${ }^{2}$ \\ ${ }^{1}$ Departamento de Zoologia, Instituto de Biologia, Universidade Federal do Rio de Janeiro, CCS, Bloco A, 21491 - \\ 590, Rio de Janeiro, RJ. ${ }^{2}$ Departamento de Bioquímica, Instituto de Química, Universidade Federal do Rio de \\ Janeiro, CT, Bloco A, 21910-240, Rio de Janeiro, RJ.
}

\begin{abstract}
This work aimed to know the tolerance mechanisms through the salinity variation by $\mathrm{Na}^{+} \mathrm{K}^{+}-\mathrm{ATPase}_{\mathrm{and}} \mathrm{Mg}^{++}$ATPase and enzymes encountered in the gills of Poecilia vivipara. In field, the presence of this species was observed in salinities of 0 and $28 \%$. In laboratory, these fish were maintained in aquarium with mean salinity of $30 \%$ and positive responses were obtained. Some adult specimens, collected in a lagoon of the Coqueiros Beach, were utilized as matrixes. In the experiments the specimens used were those born in the test aquarium. For each salinity studied three replicates were made with three specimens for each one. The alevins were maintained in salinities of $5,10,15,20,25,30$ and 35\%o during a month for adaptation. Gills were extracted in appropriate buffer for isolation of plasma membrane and used for specific dosage of the total enzymatic activity of $\mathrm{Na}^{+} \mathrm{K}^{+}$- ATPase and $\mathrm{Mg}^{++}$- ATPase. The relation of alevins to their adaptation towards the salinity variation was also studied. The activity of the two enzymes showed a different result. The major expression of $\mathrm{Na}^{+} \mathrm{K}^{+}-$ATPase was observed in 20\%o (35 $\mu$ moles Pi.mg protein. $h^{-1}$ ), the best salinity to cultivate P. vivipara.
\end{abstract}

Key words: Poecilia vivipara, $\mathrm{Na}^{+} \mathrm{K}^{+}$ATPase, $\mathrm{Mg}^{++}$ATPase, osmoregulation

\section{INTRODUCTION}

Poecilia vivipara (Bloch \& Schneider, 1801) belongs to the family Poeciliidae and presents wide geographical distribution, being found in the Americas, from Illinois and New Jersey (EUA) to Argentina (Nascimento, 1984). They are commonly found in salt and brackish waters, mainly in the exits of ponds and river mouths
(Suzuki, 1983). The individuals of this species are viviparous with internal fertilization. They present sex dimorphism, where the males possess an organ formed by the transformation of the anal fin in aid of the sexual intercourse (Nomura, 1984). The rays of the anal fin, particularly the third, fourth and fifth ones, are longer than the others. They are independent in the beginning of the development, coming unfastened later in the whole length,

\footnotetext{
* Author for correspondence
} 
creating the gonopodium. The reproduction is continuous throughout the year. The females begin reproducing from $3 \mathrm{~cm}$ of total length, in continuous gestations. When they reach approximately $7 \mathrm{~cm}$ of length, they present an average of 51 embryos per gestation (Novaes \& Andreata, 1994) The females have the ventral region permanently dilated by the continuous gestations. Thus, they are vulgarly called "Barrigudinho" (Pereira, 1979). These fish are omnivorous and they participate in the trophic chain, serving as food for carnivorous fish (Koblitz \& Andreata, 1994; Novaes \& Andreata, 1994).

$P$. vivipara was used in tests of thermal tolerance, lethal effects of cadmium and tests with derivatives of petroleum in Venezuela (Chunk, 1983; Chunk \& Mendez, 1993) and in China (Xu et al., 1991; Xu et al., 1992). Damato (1995) used three species of fish, one of them belonging to $P$. vivipara, in toxicity tests with potassium dichromate. P. vivipara presented high sensitivity, suggesting its employment as biological indicator. The species Poecilia reticula and P. sphenops are cultivated for use in tests of aquatic effluents in Venezuela (Grau \& Esclapés, 1995). Kraus et al. (1998) tested the sensitivity of $P$. vivipara to four reference substances (potassium dichromate, sodium dodecyl sulfate, copper and zinc).

In natural conditions $P$. vivipara is found in environments that differ from its geological and physiographical characteristics, such as salt concentrations and they are under different degrees of anthropogenetic impact (Caniçali \& Lima, 1996). In the Coqueiros Beach, where the individuals were collected, the salinity varies from 0 to $28 \%$ o (Amaral, 1997). The aim of this study was to dose $\mathrm{Na}^{+} \mathrm{K}^{+}$- ATPase and $\mathrm{Mg}^{++}$ATPase enzymes that are responsible for the individuals' osmoregulation.

\section{MATERIAL AND METHODS}

Adult specimens were captured with nets in a lagoon in Coqueiros Beach at Fundão Island, in contact with the waters of Guanabara Bay. The fish were transported to the laboratory in sea water and conditioned in an acclimatized aquarium. The proportion of two females for a male was maintained. After the birth, the alevins were placed in test aquariums with the capacity of $1,000 \mathrm{ml}$, being standardized in $300 \mathrm{ml}$ of sea water for each individual with a salinity of $30 \%$ o. For seven consecutive days the salinity was gradually reduced and later they were maintained in 5, 10, $15,20,25,30$ and $35 \%$. For each salinity studied, three replicates were made with three specimens for each one during a month for total adaptation. The aquariums were aerated and maintained in an incubator with controlled temperature at $25 \pm 2^{\circ} \mathrm{C}$ and a 12-hour photoperiod. The alevins were fed twice a day with ration in flakes (Tetra Min) and nauplius of Artemia sp. "ad libitum".

For enzyme extraction, the gills were removed, dried with absorbent paper, and weighed in analytical balance. The membrane's cells of the gills of $P$. vivipara were isolated for dosage of the $\mathrm{Na}^{+} \mathrm{K}^{+}$- ATPase and $\mathrm{Mg}^{++}$- ATPase activities (Bouef et al., 1978; Harache et al., 1980). Stages of the membrane isolation for determination of the ATPase activity: (1) Homogenization in the Ultra Turrax of $0.2 \mathrm{~g}$ of tissue in $0.5 \mathrm{ml}$ of Tris buffer 5 $\mathrm{mM}$, Sucrose solution $0.25 \mathrm{mM}$, EGTA (EthyleneGlycol bis $\beta$ aminoethylether) $\mathrm{N}-\mathrm{N}$ ' Tetra-acetic Acid) $0.2 \mathrm{mM}, \mathrm{pH}$ 7.4. Time of homogenization 1.5 min per 7,000 rpm at $4 \mathrm{C}$. (2) Centrifugation at $8,714 \mathrm{xg}$ for $10 \mathrm{~min}$ and removed the supernatant. (3) Centrifugation at $61,000 \mathrm{xg}$ for $45 \mathrm{~min}$. (4) Ressuspension in $1.5 \mathrm{ml}$ of homogenization buffer in the Potter and preparation of a gradient 1:1 with the Tris buffer $5 \mathrm{mM}$, Sucrose solution $1.4 \mathrm{M}$, EGTA $0.2 \mathrm{mM} \mathrm{pH} 7.4$ and centrifugation at 61,000 $\mathrm{xg}$ for $45 \mathrm{~min}$. (5) Remotion of the membrane fraction and dilution of 5 times with Tris-EGTA buffer $0.2 \mathrm{mM} \mathrm{pH} 7.4$ and centrifugation at 61,000 $\mathrm{xg}$ for $45 \mathrm{~min}$. (6) Ressuspension in $1.5 \mathrm{ml}$ with imidazole buffer $25 \mathrm{mM}$, Sucrose $0.25 \mathrm{mM}$, EGTA $0.2 \mathrm{mM} \mathrm{pH}$ 7.4. (7) Evaluation of the ATPase activity.

Dosage of $\mathrm{Na}^{+}, \mathrm{K}^{+}$- ATPase and $\mathrm{Mg}^{++}$ATPase: The total enzymatic activity of the ATPase was determined by the incubation of the enzyme at $37^{\circ} \mathrm{C}, \mathrm{pH} 7.5$ in a solution (final volume equal to $0.5 \mathrm{ml}$ ) containing ATP.Na $\mathrm{N}_{2}$-TRIS $5 \mathrm{mM}$, $\mathrm{NaCl} 150 \mathrm{mM}$ (final concentration of $\mathrm{Na}^{+} 155$ $\mathrm{mM}), \mathrm{KCl} 15 \mathrm{mM}, \mathrm{MgCl} 15 \mathrm{mM}$ in histidine $\mathrm{HCl}$ 
TRIS $30 \mathrm{mM}$. The dosage of $\mathrm{Mg}^{++}$- ATPase was made under identical conditions. However, oubain was added in the final concentration of $1.5 \mathrm{mM}$. The $\mathrm{Na}^{+}, \mathrm{K}^{+}$- ATPase activity is obtained by the difference between the total activity and the $\mathrm{Mg}^{++}$ - ATPase activity. For each sample, a reference solution was prepared in which the enzyme was added after the paralyzation of the reaction. The tubes containing the enzyme were pre-incubated for $5 \mathrm{~min}$ at $37^{\circ} \mathrm{C}$. The reaction was started with the addition of ATP and paralyzed with the addition of $1 \mathrm{ml}$ of reagent for dosage of inorganic phosphates $(\mathrm{Pi})$ after $10 \mathrm{~min}$ of incubation at $37^{\circ} \mathrm{C}$. The tubes rested for 15 to $20 \mathrm{~min}$ at room temperature and each one of the tubes (total ATPase, $\mathrm{Mg}^{++}$- ATPase and "reference solution") was read at $700 \mathrm{~nm}$ by the modified method of Fiske \& Subbarow (1925). Patterns of sodium phosphate were prepared concomitantly.

$\mathrm{Na}^{+}, \mathrm{K}^{+}$- ATPase and $\mathrm{Mg}^{++}$- ATPase activities were expressed in $\mu$ moles of Pi released per hour per milligram of protein ( $\mu$ moles Pi.mg protein. $\mathrm{h}^{-1}$ ) of the preparation adapted for Ortiz (1975).

Dosage of Protein: Protein concentration was measured by the modified method of Lowry et al. (1951). The band of protein was 1 to $100 \mu \mathrm{g}$, read at $700 \mathrm{~nm}$ for $1.1 \mathrm{ml}$ (microassay) at room temperature after $5 \mathrm{~min}$. Serum of bovine albumin was used as a pattern.

\section{RESULTS AND DISCUSSION}

The $\mathrm{Na}^{+} \mathrm{K}^{+}$- ATPase activity of $P$. vivipara was of $33.6 \mu$ moles Pi per hour per $\mathrm{mg}$ of protein, presenting the same order of magnitude as $\mathrm{Na}^{+} \mathrm{K}^{+}$ - ATPase of Oncorhynchus kisutch (salmon) (Harache et al., 1980). In relation to this enzyme of Tilapia rendalli, the activity was about ten times higher (Arbex, 1983). This study demonstrated that $\mathrm{Na}^{+} \mathrm{K}^{+}$- ATPase activity of $P$. vivipara was very similar to fishes, which were adapted to salinity variations. The concentration effect of EGTA was tested in the homogenization buffer and it was found that the ATPase activity in the extract free from cell was sensitive from 0.2 mM onwards (Fig. 1).
The results for $\mathrm{Na}^{+} \mathrm{K}^{+}$- ATPase and $\mathrm{Mg}^{++}$ATPase demonstrated that they were enzymes totally different in relation to their kinetics parameters. These enzymes presented inhibition kinetics for substratum excess (type accompetitive) and Michaeliana, respectively (Fig. 2).

Their kinetic parameters were determined by non lineal programs in microcomputer by the algorithm of the Marquardt of Enzifit. The curves are theoretical and the points are experimental. The Vmax for enzyme $\mathrm{Na}^{+} \mathrm{K}^{+}$ATPase was $153.62 \pm 41.22 \mathrm{mM}$ and the $\mathrm{Km}$ was $3.57 \pm 1.10$ $\mathrm{mM}$. This enzyme presented a Kis of $1.86 \pm 0.75$ $\mathrm{mM}$. The Vmax of enzyme $\mathrm{Mg}^{++}$ATPase was $280.79 \pm 11.69 \mathrm{mM}$ and the $\mathrm{Km}$ was $0.36 \pm 0.03$ $\mathrm{mM}$. The parameters determined presented quite different values from $\mathrm{Na}^{+}, \mathrm{K}^{+}$- ATPase of the Tilapia rendalli in relation to the $\mathrm{Km}$ for ATP. $\mathrm{Mg}^{++}$that is $0.53 \mathrm{mM}$. They presented a much higher value $(3.618 \pm 0.3 \mathrm{mM})$ and this enzyme presented a Kis of $1.795 \mathrm{mM}$ showing an inhibition for substract not reported for the enzyme of Tilapia rendalli (Arbex, 1983). The adjustment of the experimental data of this kinetics to the Michaeliana equation did not fit better than the equation for inhibition for substract. 


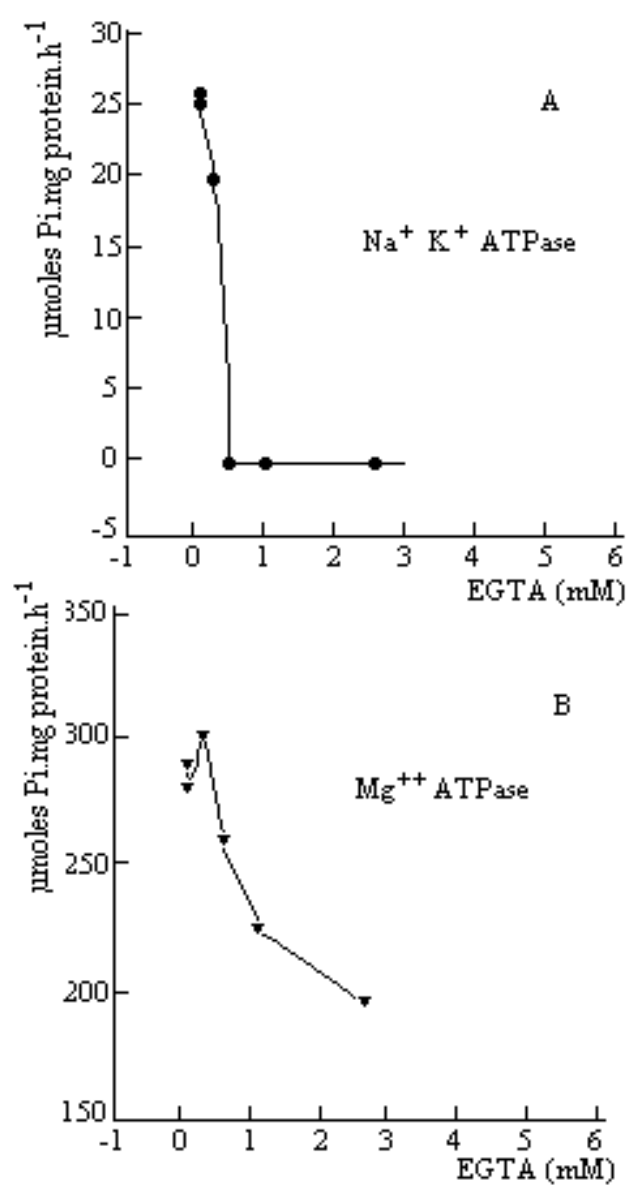

Figure 1 - EGTA effect in the ATPase activity in gills of P. vivipara.

The value of $\mathrm{Km}$ for $\mathrm{Mg}^{++}$- ATPase was in accordance with the values found for this enzyme in the literature. These values were for enzymes of gills of $P$. vivipara adapted to the salinity of $30 \%$ o. $\mathrm{Na}^{+} \mathrm{K}^{+}$- ATPase was an integral protein of membrane found in cells of superior eucaryotes and it was responsible for translocate ions of sodium and potassium through the membrane of cells using ATP as a driving force. For every three ions of sodium pumped off the cell, two potassium ions were pumped in. Such protein was specifically inhibited by cardiac glycosides, as, for example, ouabain and digoxin (Lingrel \& Kuntzweiler, 1994).
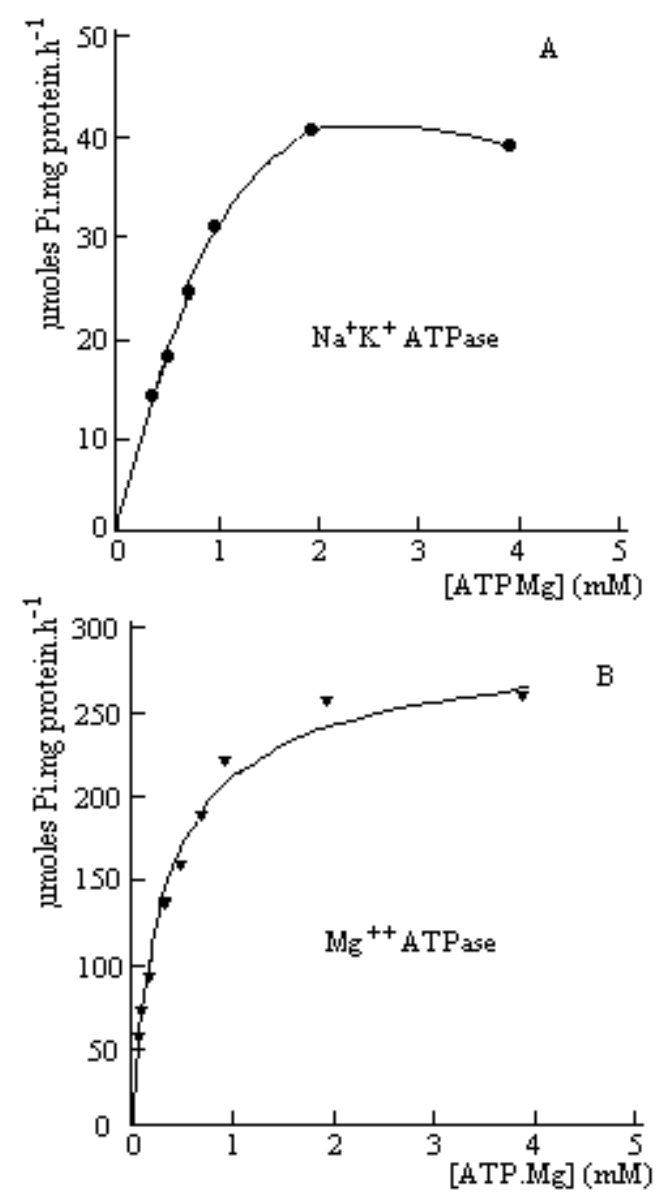

Figure 2 - ATP. $\mathrm{Mg}^{++}$effect in the ATPase activity in gills of $P$. vivipara.

$\mathrm{Na}^{+} \mathrm{K}^{+}$- ATPase presented inhibition for $1.5 \mathrm{mM}$ of oubain and its activity for $\mathrm{Na}^{+}$and $\mathrm{K}^{+}$, was optimum in the relationship of $150 \mathrm{mM}$ and $15 \mathrm{mM}$, respectively. These concentrations were in accordance with the literature for Tilapia rendalli (Arbex, 1983) and Oncorhynchus kisutch (Harache et al., 1980). The activity of $\mathrm{Na}^{+} \mathrm{K}^{+}$ATPase presented a maximum of the expression of the enzyme in $20 \%$ o. Higher concentrations presented a decrease in the activity (Fig. 3). This result was not expected once it should have been around $35 \mu$ moles Pi.mg protein. $h^{1}$. The difficulty of maintaining the high levels could be related to the stress accumulated from this value of $20 \%$ and linked to a factor that modified the activity $\mathrm{Na}^{+}, \mathrm{K}^{+}$ - ATPase "in vivo". $\mathrm{Na}^{+} \mathrm{K}^{+}$- ATPase increased its activity 7 times in the adaptation to the salinity. Its basal activity was of $5.4 \mu$ moles Pi.mg 
protein. $\mathrm{h}^{-1}$. All the activities found in the salinity variation were in accordance with the expected for O. kisutch (Harache et al., 1980). $\mathrm{Mg}^{++}$ATPase activity during the adaptation to the salinity was different from the one found for this fish, once it followed the $\mathrm{Na}^{+} \mathrm{K}^{+}$- ATPase profile, presenting a maximum in $20 \%$.

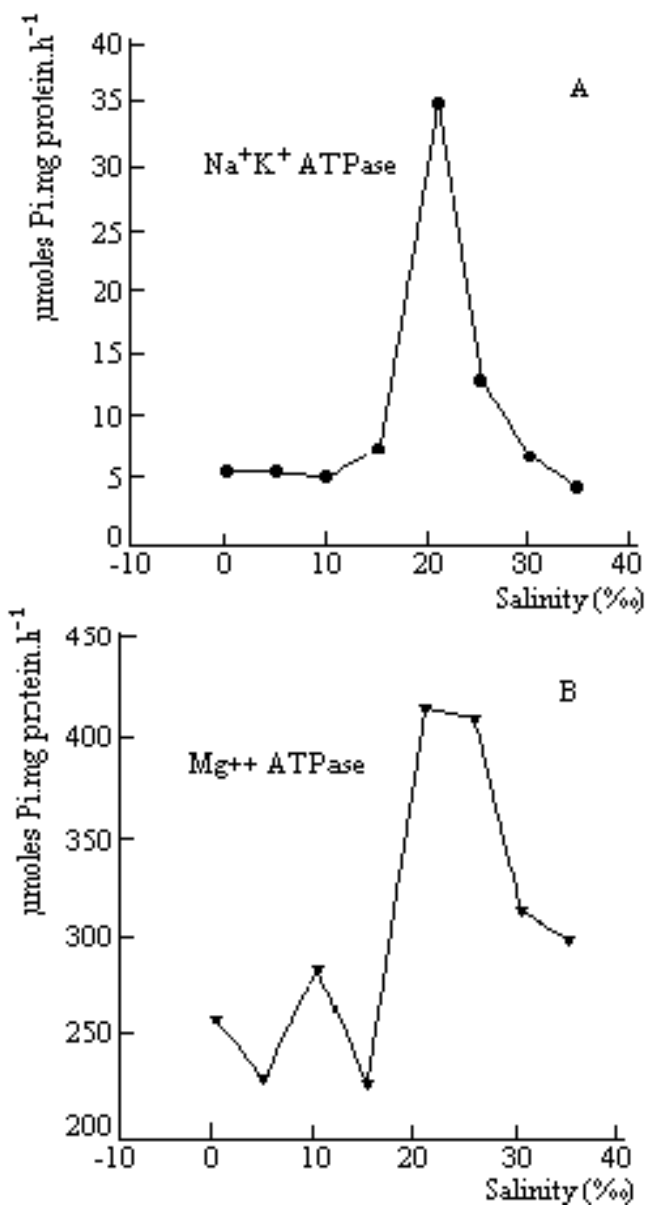

Figure 3 - Salinity effect in the ATPase activity in gills of $P$. vivipara.

\section{ACKNOWLEDGEMENTS}

We thank to Prof. Dr. Sérgio L. C. Bonecker for his help in the preparation of the manuscript and the Council of Teaching for Graduated from UFRJ for the financial support.

\section{RESUMO}

Este trabalho teve como objetivo conhecer os mecanismos de tolerância às variações de salinidade, pelas enzimas $\mathrm{Mg}^{++}$- ATPase e $\mathrm{Na}^{+}$ $\mathrm{K}^{+}$- ATPase, encontrada nas brânquias de Poecilia vivipara. No campo, foi observada a presença desta espécie em salinidades entre $0 \mathrm{e}$ $28 \%$. No laboratório, os indivíduos foram mantidos em salinidade de $30 \%$ e responderam positivamente. Os indivíduos adultos, coletados em uma lagoa na praia dos Coqueiros, foram utilizados como matrizes. Nos experimentos foram usados alevinos que nasceram nos aquários testes. Para cada salinidade estudada foram feitas três réplicas com três espécimens em cada uma. Os alevinos foram mantidos em salinidades de 5, 10, 15, 20, 25, 30 e $35 \%$, durante um mês para total adaptação. As brânquias foram extraídas em tampão apropriado para isolar a membrana plasmática e usada dosagem específica para a atividade enzimática total de $\mathrm{Na}^{+} \mathrm{K}^{+}$ATPase e $\mathrm{Mg}^{++}$ATPase e sua relação a adaptação da variação da salinidade. A atividade das duas enzimas mostrou diferentes resultados. A maior expressão de $\mathrm{Na}^{+}$ $\mathrm{K}^{+}$- ATPase foi observada em 20\%o (35 $\mu$ moles $\mathrm{Pi} / \mathrm{mg}$ proteína.h), sendo a melhor salinidade para se manter o cultivo de $P$. vivipara.

\section{REFERENCES}

Amaral, M. da C. (1997), Avaliação da espécie Poecilia vivipara (Bloch \& Schneider, 1801) para utilização em experimentos de laboratório. Monografia. Instituto de Biologia, Universidade Federal do Rio de Janeiro. 44p.

Arbex, O.F. (1983), $\mathrm{Na}^{+} \mathrm{K}^{+}$ATPase em brânquias $e$ intestino de Tilapia rendalli: uma comparação cinética. Dissertação de Mestrado. Instituto de Química, Universidade Federal do Rio de Janeiro. 67p.

Boeuf, G.; Lasserre, P. \& Harache, Y. (1978), Osmotic adaptation of Oncorhychus kisutch Walbaum. II. Plasma osmotic and ionic variations, and gill $\mathrm{Na}^{+}-\mathrm{K}^{+}$ ATPase activity of yearling coho salmon transferred to sea water. Aquaculture 15(1):35-52.

Caniçali, M.R. \& Lima, N.R.W. (1996), Plasticidade fenotípica em quatro populações de Poecilia vivipara (Teleostei: Poeciliidae) do norte fluminense. I Jornada de Ictiologia do Rio de Janeiro, Rio de Janeiro, p. 20 (em resumo). 
Chunk, K.S. (1983), Lethal effects of cadmium in tropical fishes. Bull. Jap. Sci. Fish. Nissuishi 49 (10):15651568.

Chunk, K.S. \& Mendez, S. (1993), Comparative thermal tolerance of some tropical fishes of Venezuela. Ciencia-Maracaibo 1(1):1-7.

Damato, M. (1995), Determinação da toxicidade aguda de dicromato de potássio para Phalloceros caudimaculatus, Poecilia vivipara e Cyprinus carpio. XI Encontro Brasileiro de Ictiologia, Campinas, p.E7-E8 (em resumo).

Fiske, E.H. \& Subbarow, Y.V. (1925), The colorimetric determination of phosphorus. Biol. Chem., 66:375400.

Grau, J.R. \& Esclapés, M.M. (1995), Protocolos estándares para bioensayos de toxicidad com especies acuáticas. Gerencia General de Tecnologia. Departamento de Ecología y Ambiente. Versión 1.0. $109 \mathrm{p}$.

Harache, Y., Boeuf, G. \& Lasserre, P. (1980), Osmotic adaptation of Oncorhychus kisutch Walbaum. III. Survival and growth of juvenile coho salmon transferred to sea water at various times of the year. Aquaculture 19:253-273.

Kraus, L.A. da S.; Bonecker, A.C.T. \& Vital, N. de A.A. (1998), Acute Toxicity of Potassium dichromate, Sodium Dodecyl Sulfate, Copper and Zinc to Poecilia vivipara (Osteichthyes, Cyprinodontiformes). Fresenius Envir. Bull. 7:654-658.

Koblitz, J.L. \& Andreata, J.V. (1994), Hábitos alimentares de Poeciliidae e Jenynsiidae da Lagoa Rodrigo de Freitas, Rio de Janeiro, Brasil - Resultados preliminares. XX Congresso Brasileiro de Zoologia, Rio de Janeiro, p. 163 (em resumo).

Lingrel, J.B. \& Kuntzweiler, T. (1994), $\mathrm{Na}^{+}, \mathrm{K}^{+}$- ATPase. J. Biol. Chem. 269(31):19.659-19.662.

Lowry, O.H.; Rosebrough, N.I; Farr, A.L. \& Randall, R.J. (1951), Protein measurement with the phenol reagent. J. Biol. Chem. 193:265-275.
Nascimento, E.P. (1984), Aspectos quantitativos da biologia do desenvolvimento de Phalloceros caudimaculatus e Poecilia reticulata (Pisces, Poeciliidae). Dissertação (Mestrado), Instituto de Biociências, Universidade de São Paulo, 120p.

Novaes, J.L.C \& Andreata, J.V. (1994), Aspectos reprodutivos de Poecilia vivipara (Bloch \& Schneider, 1801) e Jenynsia lineata (Jenyns, 1842) da Lagoa Rodrigo de Freitas, Rio de Janeiro - Resultados preliminares. XX Congresso Brasileiro de Zoologia, Rio de Janeiro, p. 162 (em resumo).

Nomura, H. (1984), Dicionário de Peixes do Brasil. Brasília, Ed. Editerra. 482p.

Ortiz, CH.D. (1975), Dosagem da $\mathrm{Na}^{+} \mathrm{K}^{+}$ATPase nas etapas de purificação de membrana plasmática de fígado de rato. Dissertação de Monografia, Instituto de Biologia, Universidade do Estado do Rio de Janeiro. 9p.

Pereira, R. (1979), Peixes da Nossa Terra. São Paulo, Ed. Nobel. 495p.

Suzuki, C.R. (1986), Guia de Peixes do Litoral Brasileiro. Edições Marítimas Ltda. 394p.

Xu, X.; Cai, C. \& Li, H. (1991), Quantum-chemical study on toxicities of clorobenzenes to some aquatic species. J. Zhanjiang Fish. Coll. Zhanjiang Shuichan Xueyuan Xuebao 11(2):64-66.

Xu, X.; Lu, Y. \& Li, H. (1992), Quantum chemical study on quantitative relationships between structure and toxicities of chlorophenols to some aquatic species. $J$. Zhanjiang Fish. Coll. Zhanjiang Shuichan Xueyuan Xuebao 12(2):60-64.
Received: August 13, 1998; Revised: September 27, 1999; Accepted: April 07, 2000. 